\title{
Influence of Treated POME Sludge Vermicomposting on Soil Physicochemical Properties and Maize Growth Performances
}

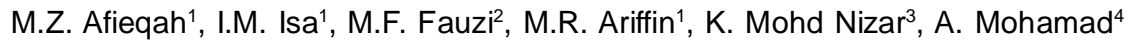

10.18805/IJARe.A-640

\begin{abstract}
Background: Transforming the abundance of palm oil mill effluent (POME) sludge into beneficial substances such as an organic amendments is vital in the recycling of waste. Vermicomposting from treated POME sludge (TPS) was evaluated on the effect of soil physicochemical properties, crop performances and to determine the best treatment effect on the biomass of the hybrid grain maize (Zea mays L.).

Methods: The experimental layout was designed in a randomized complete block design (RCBD). The grain maize cultivated in Bungor series soil (Ultisol) comprising of (T1) control (NPK fertilizer), (T2) $1 \mathrm{~kg}$ of vermicompost, (T3) $2 \mathrm{~kg}$ vermicompost, (T4) $1 \mathrm{~kg}$ TPS and T5 (2 kg TPS) with six replications, for a period of 100 days from June to September 2019. Half of the NPK fertilizer dosage applied from the recommended practices.

Result: The treatments with $50 \%$ reduction of NPK rate significantly $(p<0.05)$ affected soil physicochemical properties. The dry matter production, crop performance analysis (net photosynthesis, stomata conductance and transpiration rate) and root weight density were also increased significantly using $2 \mathrm{~kg}$ of vermicompost treatment. Vermicompost application demonstrated the best treatment effect on soil properties and grain maize productivity. Utilization of POME sludge waste into organic amendment through vermicomposting approach would become very crucial practices to be adopted in reducing the abundance waste.
\end{abstract}

Key words: Grain maize, Physicochemical, POME, Productivity, Vermicomposting.

\section{INTRODUCTION}

POME sludge is a residue commonly referred to as oil extraction by palm oil mills which is stored or discharged in disposal ponds, leading to the leaching of heavy metals to the groundwater and soil. POME was highlighted by palm oil mills operators as an expensive and difficult waste to manage (Madaki and Seng, 2013). Directly applied to the agricultural fields could cause soil-environmental problems like phytotoxicity (Breś and Politycka, 2016). Research from Khairuddin et al., (2016), the treated POME sludge waste was safe for plant uptake (Association et al., 1915). The waste had the potential to convert into an organic amendment for plant growth (Mohd Nizar et al., 2018).

The emphasis of this study is to minimize the waste by converting it into vermicompost. Vermicomposting the treated POME sludge (TPS) is one of the most efficient means to mitigate and manage environmental pollution problems. The earthworm ingested TPS and yielded a peat-like material which called as vermicompost. This process is faster than traditional composting as the material passes through the earthworm gut, resulting in microbial activity and plant growth regulators (Pathma and Sakthivel, 2012).

A review by Rupani et al., (2010), vermicomposting from POME sludge was one of the practical and effective practices. A technology in vermicomposting the TPS is expected to produce high grain maize (Zea mays L.) biomass yield production, highlighting comparable results with TPS and chemical fertilizer and also able to improve soil physicochemical conditions.
'Department of Land Management, Faculty of Agriculture, Universiti Putra Malaysia, 43400 Serdang, Selangor, Malaysia.

${ }^{2}$ Department of Crop Science, Faculty of Agriculture, Universiti Putra Malaysia, 43400 Serdang, Selangor, Malaysia.

3Oil Palm Agronomy, FGV RandD Ptd. Lt., Tun Razak Center of Agriculture Research, 26400 Bandar Tun Abdul Razak Jengka, Malaysia.

${ }^{4}$ Centre of Foundation Studies for Agricultural Sciences, Universiti Putra Malaysia, 43400 Serdang, Selangor, Malaysia.

Corresponding Author: I.M. Isa, Department of Land Management, Faculty of Agriculture, Universiti Putra Malaysia, 43400 Serdang, Selangor, Malaysia. Email: imi@upm.edu.my

How to cite this article: Afieqah, M.Z., Isa, I.M., Fauzi, M.F., Ariffin, M.R., Mohd Nizar, K. and Mohamad, A. (2021). Influence of Treated POME Sludge Vermicomposting on Soil Physicochemical Properties and Maize Growth Performances. Indian Journal of Agricultural Research. DOI: 10.18805/IJARe.A-640.

Submitted: 31-03-2021 Accepted: 08-10-2021 Online: 07-11-2021

\section{MATERIALS AND METHODS}

TPS was sampled at oil palm mills situated in Felda Jengka 8, Pahang, Malaysia. The selected dumping pond (DP) as a storage of POME sludge was initially treated with specific Hydraulic Retention Time (HRT) method which using the standard methodologies of the wastewater that was compulsory to abide during the processes. Before applying it to the worms, the moisture content of TPS was maintained at the constant level in about 2 weeks to get better aeration and to speed up the degradation purposes. 
The TPS was sieved to maintain its size $<5.18 \mathrm{~mm}$. The sieves substrate was placed in vermicomposters of 42 liter containers (length: $63 \mathrm{~cm}$; width: $47 \mathrm{~cm}$; depth: $38 \mathrm{~cm}$ ). Five hundred grams substrates were kept in moist conditions using organic liquid that mixed with the distilled water (1:10) up to $40 \%$ in weight for a week in order to soften and accelerate the degradation processes. Hundred grams of earthworms (Eudrilus eugeniae) were added to the vermicomposter and the vermicast was collected at the top layer of the vermicomposter. The moisture content of the vermicompost was kept at 30\%-40\% throughout the experimental period and stored in a shady place at the temperature of $20^{\circ} \mathrm{C}-30^{\circ} \mathrm{C}$. The substrate maintained at a depth of $25-30 \mathrm{~cm}$ and a new substrate was added. The earthworm stock maintained at the temperature of $25 \pm 1^{\circ} \mathrm{C}$. The heavy metals content in TPS (Table 2) and preliminary nutrient properties in the vermicompost (Table 3) were determined using the standard methods.

Table 1: Soil characteristic of Bungor soil series (Ultisol) before experiment.

\begin{tabular}{lc}
\hline Parameter & Value \\
\hline Series & Bungor (Ultisol) \\
pH before liming & 4.19 \\
pH after liming & 5.4 \\
Texture & Sandy clay loam \\
Clay (\%) & 27.67 \\
Silt (\%) & 8.75 \\
Sand (\%) & 63.59 \\
Total N (\%) & 0.09 \\
P (ppm) & 0.05 \\
K (ppm) & 40.15 \\
CEC (cmol kg-1) & 9.98 \\
\hline
\end{tabular}

\section{Field arrangement}

The experiment was conducted at Agrotech farm, Universiti Putra Malaysia $\left(2^{\circ} 58^{\prime} 55.0^{\prime \prime} \mathrm{N} 101^{\circ} 42^{\prime} 55.1^{\prime \prime} \mathrm{E}\right)$ (Fig 5A). The vermicompost and TPS with different rates of application mixed with $20 \mathrm{~kg}$ of Bungor series soil (Ultisol) as the planting medium filled in a polybag of $20^{\prime} \times 20^{\prime}$. Treatments evaluated were: (T1) NPK fertilizer as a control, (T2) $1 \mathrm{~kg}$ vermicompost + NPK, (T3) $2 \mathrm{~kg}$ vermicompost + NPK, (T4) $1 \mathrm{~kg}$ TPS + NPK and (T5) $2 \mathrm{~kg}$ TPS + NPK with six replications. $13 \mathrm{~g}$ of chemical fertilizer (NPK: 15:15:15) added to all the treatments for each plant 14 days after sowing and $10 \mathrm{~g}$ of chemical fertilizer (NPK: 12:12:17) after 7 days after flowering phase occurred. The experimental layout was set up in a randomized complete block design (RCBD) (Fig 5B) and the maize variety planted was the hybrid grain maize (Zea mays L.). The rate of NPK fertilizer used was half of the recommended rate as suggested by MARDI (Onn, 2005).

\section{Soil analysis}

The Bungor soil series (Ultisols) was collected from topsoil $(0-10 \mathrm{~cm})$ for preliminary data analysis. The soil samples were placed in a container and immediately transported to the laboratory for analysis. The soil characteristics of Bungor soil series before experiment showed in Table 1. After harvesting, the soil samples were collected to analyse the selected physicochemical properties using the standard methods. Aggregate stability of the soil was analysed using a wet sieving apparatus procedure (Eijkelkamp, Netherlands) adapted from Kemper and Rosenau (Kemper and Rosenau, 2018). Bulk density was conducted using the core ring method (Klute, 1986; Singh, 2016). Soil porosity was measured by the ratio of the bulk density to the particle density. Hydraulic conductivity also measured by placing the soil samples in the core ring and measured using the constant head method (Klute and Dirksen, 1986) derived

Table 2: Content of heavy metal of POME anaerobic sludge and treated POME sludge (Khairuddin et al., 2016).

\begin{tabular}{|c|c|c|c|}
\hline WHO standard & $\begin{array}{l}\text { POME anaerobic sludge } \\
\text { (Baharuddin et al., 2010) }\end{array}$ & $\begin{array}{l}\text { Treated POME sludge } \\
\text { (Khairuddin et al., 2016) }\end{array}$ & $\begin{array}{l}\text { WHO-ML } \\
\text { Standard }\end{array}$ \\
\hline \multicolumn{4}{|c|}{ Composition of heavy metal elements } \\
\hline Copper (mg/kg) & $70.40+21.60$ & $45.05+2.87$ & 75.00 \\
\hline Chromium (mg/kg) & $9.30+0.20$ & $27.86+0.55$ & 150.00 \\
\hline Cadmium (mg/kg) & n.d & $0.41+0.01$ & 1.90 \\
\hline Zinc $(\mathrm{mg} / \mathrm{kg})$ & $151.00+14.50$ & $130.11+3.49$ & 140.00 \\
\hline Lead (mg/kg) & $0.5+0.60$ & $0.38+0.10$ & 0.30 \\
\hline Nickel (mg/kg) & $14.0+2.2$ & $10.77+0.15$ & 67.00 \\
\hline Manganese(mg/kg) & $495.24+48.3$ & $422.56+12.04$ & 500.00 \\
\hline \multicolumn{4}{|c|}{ Composition of nutrient elements } \\
\hline Boron $(\mathrm{mg} / \mathrm{kg})$ & n.d & n.d & - \\
\hline Iron (\%) & $1.09+0.40$ & $2.24+0.02$ & - \\
\hline Potassium (\%) & $5.16+2.20$ & $0.03+0.01$ & - \\
\hline Calcium (\%) & $2.55+0.10$ & $1.67+0.04$ & - \\
\hline Magnesium (\%) & $1.41+0.20$ & $0.55+0.02$ & - \\
\hline Phosphorus (\%) & $1.25+0.10$ & $0.08+0.01$ & - \\
\hline Sulphur (\%) & $1.21+0.30$ & $0.30+0.01$ & - \\
\hline
\end{tabular}


Influence of Treated POME Sludge Vermicomposting on Soil Physicochemical Properties and Maize Growth Performances

Table 3: Characteristics of selected chemical composition in vermicomposting, TPS and standard organic fertilizer.

\begin{tabular}{|c|c|c|c|}
\hline Selected chemical characteristics & Vermicompost & TPS organic fertilizer & $\begin{array}{l}\text { Organic fertilizer } \\
\text { (Kala et al. 2011) }\end{array}$ \\
\hline Carbon (\%) & 12.1 & 25.53 & $\geq 12$ \\
\hline Total N (\%) & 0.7 & 4.21 & $0.70-4.40$ \\
\hline Phosphorus (\%) & 0.4 & 0.08 & $0.04-8.85$ \\
\hline Potassium (\%) & 1.0 & 0.03 & $1.29-6.94$ \\
\hline Magnesium (\%) & 0.4 & 0.55 & $0.3-3.3$ \\
\hline Calcium oxide (\%) & 0.12 & 1.67 & $0.12-12.00$ \\
\hline $\mathrm{C} / \mathrm{N}$ ratio & 17.3 & 6.1 & $3.8-42.7$ \\
\hline Moisture content (\%) & 57.9 & 68.4 & $50-70$ \\
\hline $\mathrm{pH}$ value & 8.9 & 6.2 & $4.5-9.8$ \\
\hline
\end{tabular}

from the Darcy's law. (O'neal, 1949) proposed ranges in classifying the hydraulic conductivity of soils into seven classes (Table 4).

Soil $\mathrm{pH}$ was determined using the soil to water ratio of 1:2.5 and calibrated pH meter (Rayment and Higginson, 1992). Total nitrogen content was measured using Perkin-Elmer 2400 (CNS analyzer). Soil samples were analysed using Bray's method (Bray and Kurtz, 1945) and measurement by the Auto Analyzer (AA) and the exchangeable potassium using ammonium acetate (Simard, 1993). The measurement was done using the flame atomic absorption spectrophotometer (AAS).

\section{Crop performance analysis}

The total dry matter yield (leaves, stem, cobs and roots) after harvesting was recorded. The plant samples were placed in the oven and left to dry at $60^{\circ} \mathrm{C}$ for 75 hours or until the constant weight achieved. The root sample was calculated to determine the root weight density (Yang et al., 2010). Mass of root (g) was divided with the volume of polybags $\left(\mathrm{m}^{3}\right)$. The measurements of the photosynthesis system were calculated using the LI-COR, LI-6400XT Portable Photosynthesis System (Lincoln Nebraska USA). These measurements were done before the harvesting processes at the 100 DAS.

\section{Statistically analysis}

One-way ANOVA design was adopted and the data analysed using the Statistical Analysis System (SAS 9.4) to observe the significant difference between the treatments and Pearson's coefficient correlation to observe the relationship of some selected parameters in this study. Means separation was carried out using LSD and Tukey test at $p<0.05$.

\section{RESULTS AND DISCUSSION}

\section{Preliminary of nutrients properties}

The comparison of the nutrients content in vermicompost, treated POME sludge and other organic fertilizers properties were shown in Table 3. The $\mathrm{pH}$ value in vermicompost was quite high or alkaline compared to the TPS and the other organic fertilizers. A few nutrients did not show too much differences such as total $\mathrm{N}, \mathrm{P}, \mathrm{K}$ and $\mathrm{Mg}$ content in the vermicompost and TPS organic fertilizer.
Table 4: Soil hydraulic conductivity classes (O'Neal, 1949).

\begin{tabular}{lc}
\hline Class & Hydraulic \\
\hline Very slow & $<0.125$ \\
Slow & $0.125-0.5$ \\
Moderately slow & $0.5-2$ \\
Moderate & $2-6.25$ \\
Moderate rapid & $6.25-12.5$ \\
Rapid & $12.5-25$ \\
Very rapid & $>25$ \\
\hline
\end{tabular}

\section{Selected soil physicochemical properties}

The addition of vermicompost and treated POME sludge showed that there was a significant effect $(p<0.05)$ on $(A)$ total porosity, (B) bulk density and (C) aggregate stability and (D) hydraulic conductivity (Fig 1). In Fig $1 \mathrm{~A}$ shows that vermicompost, T3 $(68.08 \%)$ had the highest mean value of total porosity compared to the control (47.25\%). Organic matter is lighter and more porous than an equivalent amount of solid soil which indicated low bulk density. Soil treated with $2 \mathrm{~kg}\left(0.85 \mathrm{~g} / \mathrm{cm}^{3}\right)$ of vermicompost showed the lowest value of bulk density (Fig 1B). The same result exhibited by Zainal, (2014). Low bulk density strengthened the soil aggregate formation (Odey, 2018). This statement proved that after treated with T3 $(76.86 \%)$ the soil aggregate formation showed the highest value in Fig $1 \mathrm{C}$ compared to the control (53.24\%).

In Fig 1D, the increased of hydraulic conductivity at 8.79 $\mathrm{cm} / \mathrm{h}$ after application of treatment with T3. High values indicated that the soil treated with vermicompost became more permeable to water to pass through the pore spaces. According to Table 4, vermicompost treatment was categorized in the moderate rapid class. Hence, the addition of vermicompost explained the increased of $\mathrm{Ks}$ due to the total soil porosity and soil aggregates stability (Fig $1 \mathrm{~A}$ and $1 \mathrm{C})$. Soil structure played a vital role in the hydraulic conductivity, either high or low (Mohd Nizar et al., 2018).

Fig 2 shows that vermicompost and TPS was significantly different $(\mathrm{p}<0.05)$ in $(\mathrm{A}) \mathrm{pH},(\mathrm{B})$ total nitrogen, (C) available phosphorus and (D) exchangeable potassium. Soil mixed with vermicompost treatment indicated the $\mathrm{pH}$ value was 6.5 compared to T1 (5.05) (Fig 2A). The difference 
in $\mathrm{pH}$ compared with the different treatments explained by the chemical content of the wastes, which contributed to the effect on mineralization processes and other intermediate compounds during the vermicomposting (Lim et al., 2015). The organic treatment improved the soil $\mathrm{pH}$ within the range of nutrients availability for plant uptake. Remaining macronutrients in the soil achieved the highest amount of nitrogen $(0.3 \%)$ after being treated with $2 \mathrm{~kg}$ of vermicompost (Fig 2B). Fig $2 \mathrm{C}$ and $2 \mathrm{D}$ showed that there was no difference of available phosphorus and potassium in vermicompost and TPS at all rates of application. Vermicompost and TPS were able to retain adequate water and nutrients. Similar results highlighted that high rate of macronutrients produced high production of grain maize (Tajul et al., 2013).

\section{Crop growth performance}

Photosynthesis rate showed the highest photosynthesis rate, $25.33 \mu \mathrm{molm}^{-2} \mathrm{~s}^{-1}$ in T3 while control $\left(15.57 \mu \mathrm{molm}^{-2} \mathrm{~s}^{-1}\right)$ with the lowest rate (Fig $3 \mathrm{~A})$. From the findings of Mahmud et al. (2019), the application of vermicompost presented positive effects on the total chlorophyll content. As the plant production in vermicompost treatment increased, the total chlorophyll content also increased and led to a higher rate of photosynthesis.
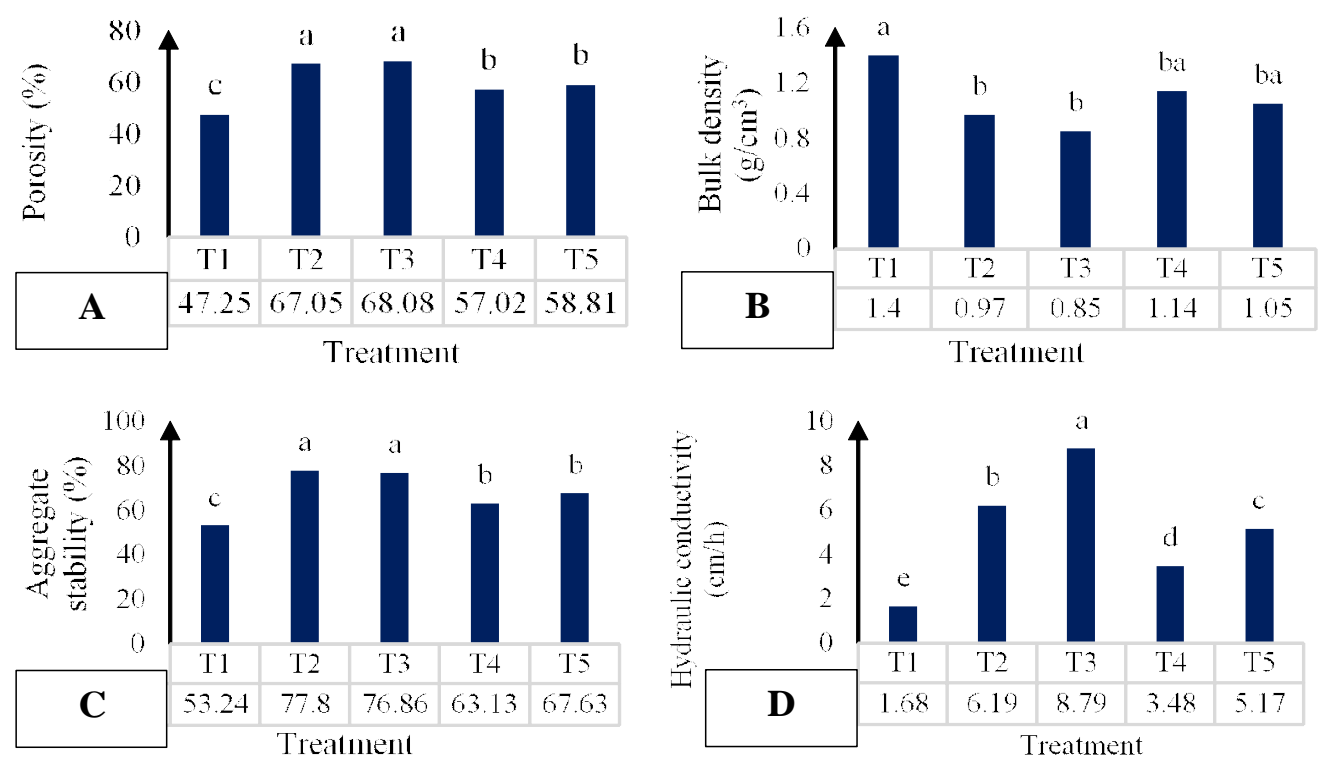

Fig 1: (A) Total porosity, (B) bulk density, (C) aggregate stability and (D) hydraulic conductivity. (Mean with the same letter is not significantly different at $\mathrm{p}<0.05)$.
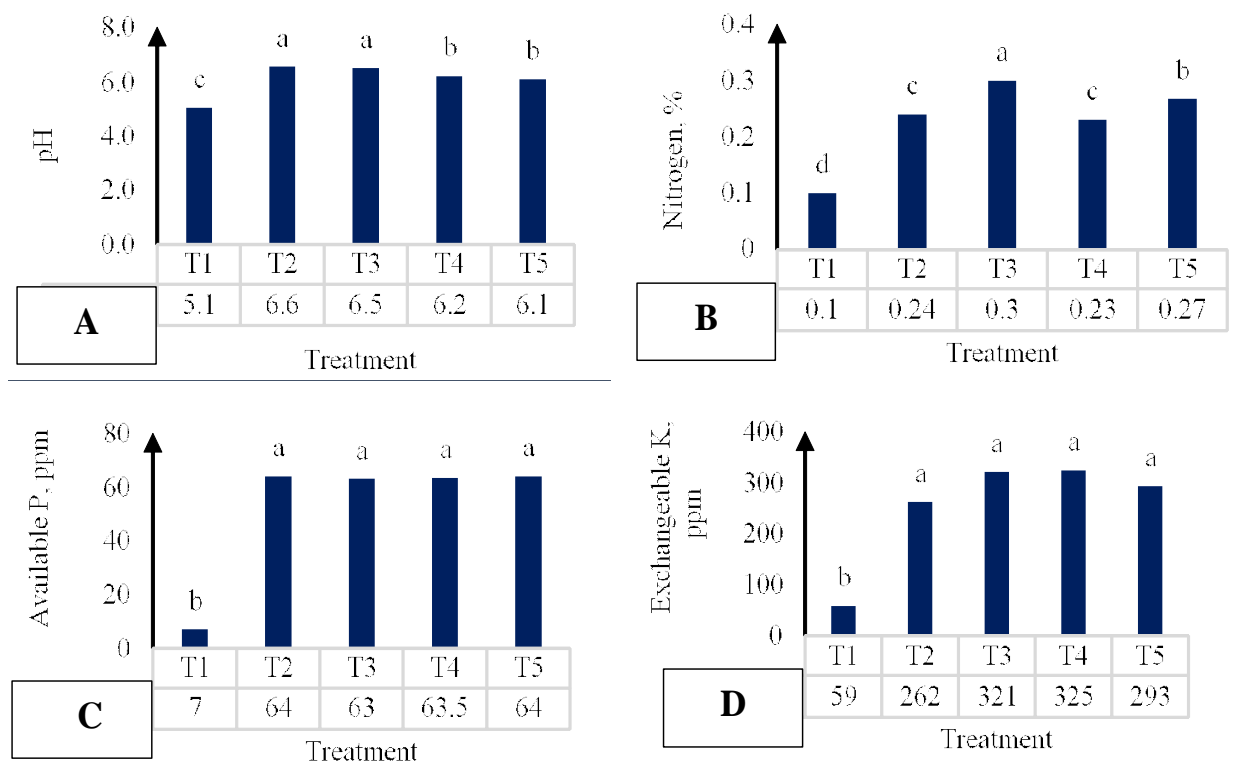

Fig 2: (A) $\mathrm{pH}$ value, (B) total nitrogen content, (C) available phosphorus and (D) exchangeable potassium. (Mean with the same letter is not significantly different at $p<0.05)$. 
Referring to Fig 3B, stomata conductance highlighted significantly different $(p<0.05)$ in T3 $\left(1.31 \mathrm{molm}^{-2} \mathrm{~s}^{-1}\right)$ than $\mathrm{T} 1$ as the control $\left(0.5 \mathrm{molm}^{-2} \mathrm{~s}^{-1}\right)$ due to the water content was sufficient in the soil, the guard cell turgor increased, leading to a rise in the stomata pore openings. The physiological maturity phase of the maize showed that vermicompost and TPS performed more effectively than the control because of a complete mineralization processes and the incorporation of the organic amendments that already occurred (Dalorima et al., 2018).

Transpiration occurred while the stomata opened for the $\mathrm{CO}_{2}$ and $\mathrm{O}_{2}$ passage to enable the process of photosynthesis. In Fig 3C, T2 showed that the transpiration rate was low in vermicompost $\left(1.11 \mathrm{~m}^{-2} \mathrm{~s}^{-1}\right)$ compared to the TPS and control treatment which might reflect to the photosynthesis effect of the maize. The high stomata
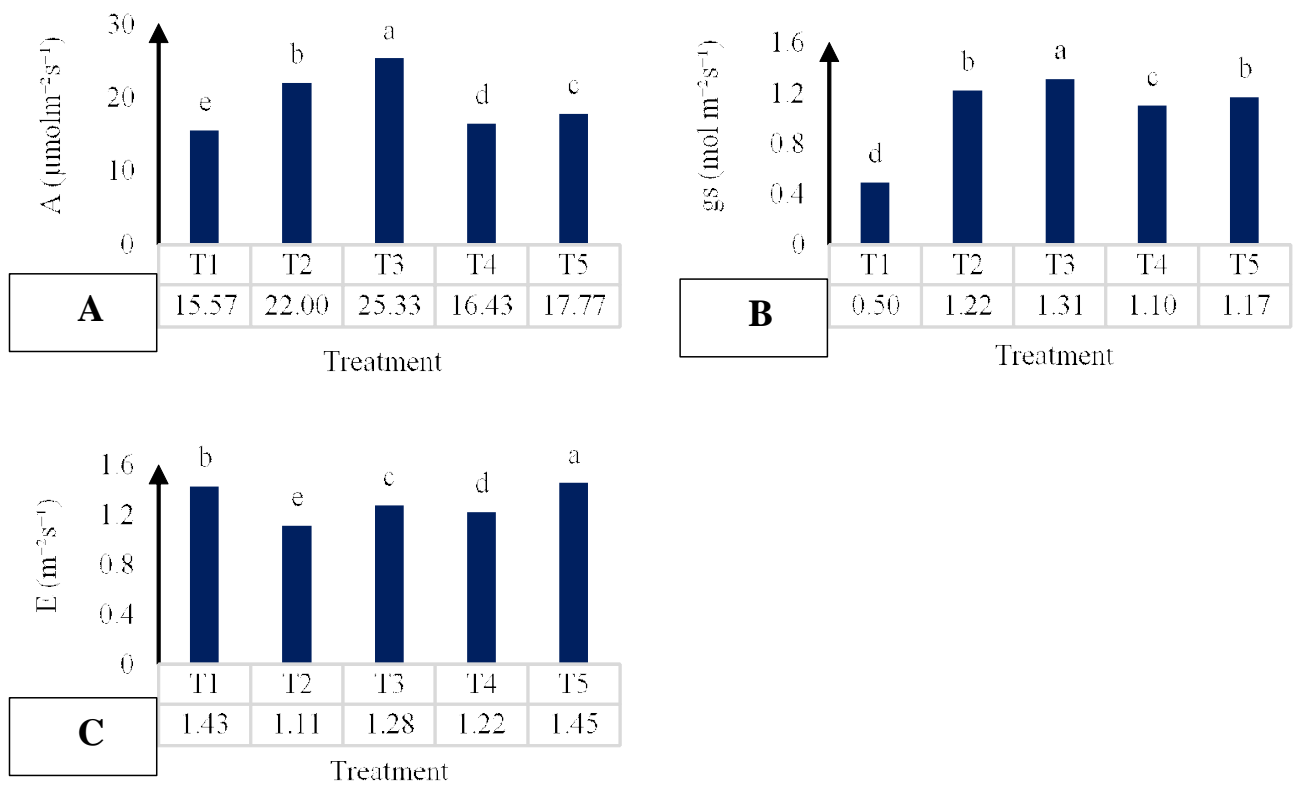

Fig 3: (A) Photosynthesis rate, (B) stomatal conductance and (C) transpiration rate of maize. (Mean with the same letter is not significantly different at $\mathrm{p}<0.05)$.
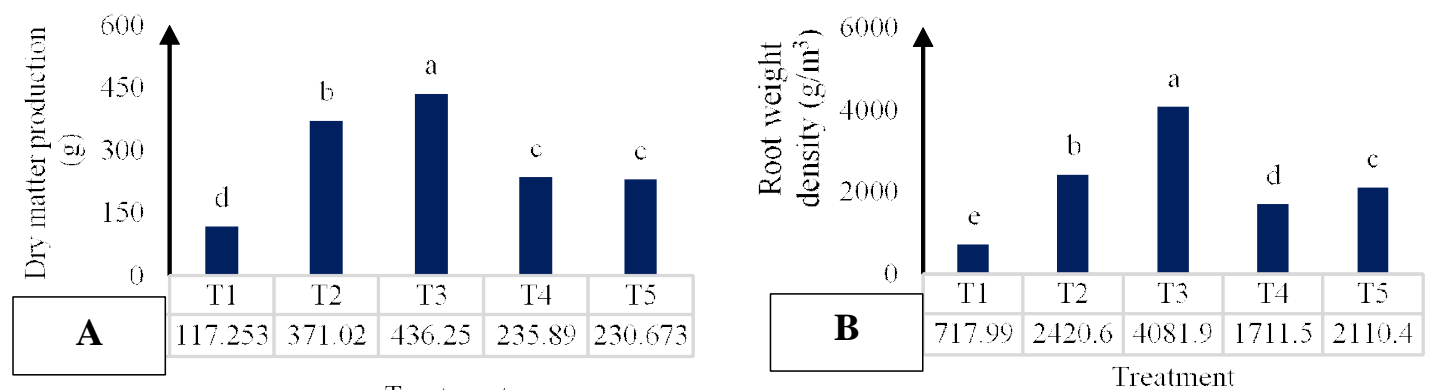

Fig 4: (A) Total dry matter production and (B) Root weight density (Mean with the same letter is not significantly different at $p<0.05$ ).

\section{A}

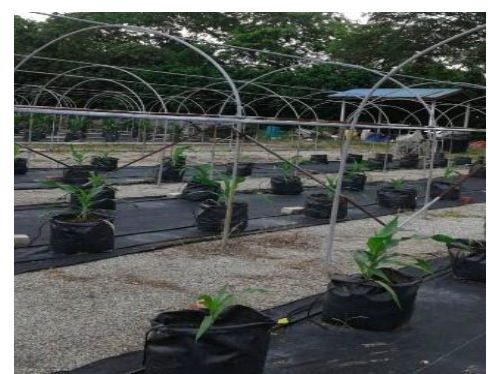

B

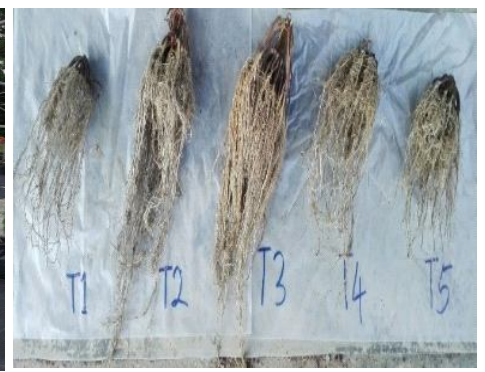

C

\begin{tabular}{|c|c|c|c|c|c|}
\hline$T_{1} R_{1}$ & $T_{4} R_{1}$ & $T_{2} R_{1}$ & $T_{5} R_{1}$ & $T_{3} R_{1}$ & $T_{1} R_{1}$ \\
\hline$T_{5} R_{1}$ & $T_{2} R_{1}$ & $T_{3} R_{1}$ & $T_{1} R_{1}$ & $T_{4} R_{1}$ & $T_{2} R_{1}$ \\
\hline$T_{2} R_{1}$ & $T_{3} R_{1}$ & $T_{1} R_{1}$ & $T_{4} R_{1}$ & $T_{5} R_{1}$ & $T_{3} R_{1}$ \\
\hline$T_{3} R_{1}$ & $T_{5} R_{1}$ & $T_{4} R_{1}$ & $T_{2} R_{1}$ & $T_{1} R_{1}$ & $T_{4} R_{1}$ \\
\hline$T_{4} R_{1}$ & $T_{1} R_{1}$ & $T_{5} R_{1}$ & $T_{3} R_{1}$ & $T_{2} R_{1}$ & $T_{5} R_{1}$ \\
\hline
\end{tabular}

Fig 5: (A) Location of the experiment, (B) Root yield of maize in all treatment and (C) Layout of the experiment. 
conductance of the maize plant in Fig 3B clearly explained its low transpiration rate.

Fig 4 showed that there was a significant difference $(p$ $<0.05)$ in dry matter production $(A)$ and root weight density (B) in T2 and T3 compared to the lowest value shown in T1. High values of macronutrients in vermicompost (Table 3 ) acts as a plant growth regulator that stimulated positive effects on crop performance (Canatoy, 2018). Hence, the application of vermicompost showed the highest root weight density. Fig 5C showed the root samples from all treatments after harvesting. The increased of root weight density in vermicompost was high compared to the TPS treatment, which due to the nutrients' availability. The application of organic amendments was one of the main reasons in providing nutrients to increase the plant vegetative growth and enhanced the condition of the kernel, loosen the soil and improved the passage of air entry for the root movement (Abaszadeh et al., 2016).

\section{CONCLUSION}

The vermicomposting of TPS using the E. eugeniae was applied to observe the effect on the grain maize growth and soil physicochemical status. Hence, there were positive and significant achievement observed on crop performances and yield of the grain maize in this study. The $2 \mathrm{~kg}$ rate of vermicompost highlighted the best result of growth production, soil structure and physiological analysis of the hybrid grain maize (Zea mays L.). As a conclusion, vermicomposting from treated POME sludge (TPS) is practical and reliable to utilize the abundant POME sludge in the oil palm mills into organic amendment for plant uptake. In the future research, cost-benefit analysis is needed to analyse the effect on the $50 \%$ reduction of inorganic fertilizer application in combination with the vermicompost whether it is economically viable and able to produce a high production of grain maize due its nutrients availability comparing to the existing fertilizing program.

\section{ACKNOWLEDGEMENT}

The authors would like to express their gratitude to Universiti Putra Malaysia for the financial support given as a Grant Putra (GP) to conduct this study. The author would also like to appreciate all members and staff for their valuable contributions in making this project a success.

\section{REFERENCES}

Abaszadeh, B., Mavandi, P., Mirza, M. (2016). Dry matter and essential oil yield changes of lavandula officinalis under cow manure and vermicompost application. Journal of Medicinal Plants and By-product. 5: 97-104.

Association, A.P.H., Association, A.W.W., Federation, W.P.C. and Federation, W.E. (1915). Standard Methods for the Examination of Water and Wastewater (Vol. 2). American Public Health Association.
Baharuddin, A.S., Hock, L.S., Yusof, M.Z., Rahman, N.A.A., Shah, U.K., Hassan, M.A., Wakisaka, M., Sakai, K., Shirai, Y. (2010). Effects of palm oil mill effluent (POME) anaerobic sludge from $500 \mathrm{~m} 3$ of closed anaerobic methane digested tank on pressed-shredded empty fruit bunch (EFB) composting process. African Journal of Biotechnology. 9: $2427-2436$

Bray, R.H. and Kurtz, L.T. (1945). Determination of total, organic and available forms of phosphorus in soils. Soil Science. 59: $39-46$.

Bres, W. and Politycka, B. (2016). Contamination of soils and substrates in horticulture. Soil Contamination - Current Consequences and Further Solutions. 23.

Canatoy, R.C. (2018). Effects of vermicompost on the growth and yield of sweet corn in Bukidnon, Philippines. Asian Journal of Soil Science and Plant Nutrition. 3: 1-8.

Dalorima, T.L., Zakaria, A.J., Majrashi, A., Mahmud, K., Mohd, K.S., Muhammad, H., Khandaker, M.M. (2018). Impacts of vermicomposting rates on growth, yield and qualities of red seedless watermelon. Australian Journal of Crop Science. 12: 1765-1773.

Kemper, W.D. and Rosenau, R.C. (2018). Aggregate stability and size distribution. Methods of Soil Analysis: Part 1 Physical and Mineralogical Methods. 5: 425-442.

Khairuddin, M.N., Zakaria, A.J., Isa, I.M., Jol, H., Nazri Wan Abdul Rahman, W.M., Salleh, M.K.S. (2016). The potential of treated palm oil mill effluent (POME) sludge as an organic fertilizer. Agrivita. 38: 142-154.

Klute, A. and Dirksen, C. (2018). Hydraulic conductivity and diffusivity: Laboratory methods. Methods of soil analysis: part 1 physical and mineralogical methods. 5: 687-734.

Klute, A. (1986). Methods of soil analysis, part 1 physical and mineralogical methods, Arnold Klute ed. Agronomy. 9, part 1.

Lim, P.N., Wu, T.Y., Clarke, C., Daud, N.N.N. (2015). A potential bioconversion of empty fruit bunches into organic fertilizer using Eudrilus eugeniae. International Journal of Environmental Science and Technology. 12: 2533-2544.

Madaki, Y.S. and Seng, L. (2013). Palm oil mill effluent (POME) from Malaysia palm oil mills: waste or resource. International Journal of Science, Environment and Technology. 2: 1138-1155.

Mahmud, M., Ramasamy, S., Othman, R., Abdullah, R., Yaacob, J.S. (2019). Effect of vermicompost application on bioactive properties and antioxidant potential of MD2 pineapple fruits. Agronomy. 9: 97.

Mohd Nizar, K., Isharudin, M.I., Abd Jamil, Z., Hazandy, A.H. (2018). Influence of treated palm oil mill effluent sludge on maize (Zea mays) growth performance and gas exchange. Sains Malaysiana. 47: 961-969.

O'neal, A.M. (1949). Soil characteristics significant in evaluating permeability. Soil Science. 67: 403-410.

Odey, S.O. (2018). Overview of engineering problems of soil compaction and their effects on growth and yields of crops. European Journal of Advances in Engineering and Technology. 5: 701-709.

Onn, L. C. (2005). Manual teknologi penanaman jagung manis. Serdang, Selangor: Institut Penyelidikan dan Kemajuan Pertanian Malaysia. 
Pathma, J. and Sakthivel, N. (2012). Microbial diversity of vermicompost bacteria that exhibit useful agricultural traits and waste management potential. SpringerPlus. 1: 1-19.

Rayment, G.E. and Higginson, F.R. (1992). Australian laboratory handbook of soil and water chemical methods. Inkata Press Pty Ltd.

Rupani, P.F., Singh, R.P., Ibrahim, M.H., Esa, N. (2010). Review of current palm oil mill effluent (POME) treatment methods: Vermicomposting as a sustainable practice. World Applied Sciences Journal. 11: 70-81.

Simard, R.R. (1993). Ammonium acetate-extractable elements. Soil Sampling and Methods of Analysis. 1: 39-42.

Singh, S. (2016). Response of Soil and water quality to winter manure application from small agricultural watersheds in South Dakota.
Tajul, M.I., Alam, M.M., Hossain, S.M.M., Naher, K., Rafii, M.Y., Latif, M.A. (2013). Influence of plant population and nitrogen-fertilizer at various levels on growth and growth efficiency of maize. The Scientific World Journal. pp: 1-9.

Yang, C.H., Chai, Q., Huang, G.B. (2010). Root distribution and yield responses of wheat/maize intercropping to alternate irrigation in the arid areas of northwest China. Plant, Soil and Environment. 56: 253-262.

Zainal, B.S. (2014). Vermicomposting of palm oil mill effluent (POME) sludge and effects of vermicompost on oil palm seedling growth. Universiti Sains Malaysia. 